\title{
Socio-Cultural and Economic Role and Importance of Biodiversity and Forest in the Democratic Republic of Congo: Case of the Upper-Katanga Province
}

\author{
Faustin Zigabe Mushobekwa ${ }^{1}$ and Bamba Bukengu Muhaya ${ }^{2}$ \\ 1. Department of Management, Faculty of Economics and Management, University of Lubumbashi, Lubumbashi 1825, Democratic \\ Republic of Congo \\ 2. Department of Chemistry, Faculty of Science, University of Lubumbashi, Lubumbashi 1825, Democratic Republic of Congo
}

\begin{abstract}
Biodiversity plays a fundamental role in the life of the Congolese population in general and in that of the population of Upper-Katanga province in particular. The current study deals with the socio-cultural and economic role and importance of biological diversity and forest in the life of the population of Upper-Katanga province. The utilized methodology was based on observation, field investigation and bibliographic research. Investigations were concerned more particularly with wood and animal species which are significantly utilized in the province. The results reflect the use of wood and animals which are part of the province biological diversity. They are compiled under two segments, namely the socio-cultural importance of biodiversity with some species forbidden to the queen, those that are utilized to split couples, to give strength to children, to provide the king with authority power, etc. The second segment deals with the results which emphasize the socio-economic importance of biodiversity concerned with hunting, fishing, cutting of some wood species for sale, building houses, cooking food, producing heat during cold weather, making furniture and other finished products, and for personal use.
\end{abstract}

Key words: Biodiversity, forest, socio-cultural and economic importance, Upper-Katanga province.

\section{Introduction}

Since the Neolithic period, men have been domesticating animals and plants to feed themselves better, to take care of their health, to get clothes and other animals for their strength, their milk, their meat, their leather... They benefit from living biodiversity in a wide range of activities and agricultural production under all the latitudes and on all the continents [1]. Biodiversity is constituted with the living organisms that surround us and to which we belong, it represents the living tissue of our planet. Its origin is very old because the first forms of life appeared on the Earth more than three billion and a half years ago. Since then, the living organisms have been changing to present the biodiversity we know today [2].

Corresponding author: Faustin Zigabe Mushobekwa, assistant lecturer, research field: environmental management.
Since a long time period, forest and wood represent important resources for the humanity. The forest plays a crucial role in the water cycle, the climate control and wood exploitation make multiple variations which represent a major challenge to the nation on ecological, economic and social plan [3]. Being the consumers who depend on wood energy, the poor people are generally the first ones who face the negative impacts which are heavy social charges, particularly the respiratory health problems. Despite those faced problems, the resident population of the Upper-Katanga province adjust themselves to the feeding, the culture and so on, an adaptation which makes them a real society. However, the Congolese biodiversity in general and that of the Upper-Katanga province in particular, is subject to threats by mining and forest exploitation, agriculture occupation of sites, wood cutting and carbonization, pirate fishing, 
military positions in the park, chasse poaching, commercial hunting, animal breeding, and human housing. There is housing destruction by itinerant agriculture on burnt down fields, hunting with bush fire, unsustainable forest exploitation inside and outside of protected areas, mining exploitation, group camping and armed gangs in protected areas. Besides, there is fauna destruction due to the destruction of habitats, to unrestrained killing of animals by unruly groups and armed gangs (Maï-Maï, FDLR, ADFNALU, LRA, SPLA), to chasse poaching with weapons for trophies and/or meat, to commercial hunting and to large scale hunting for subsistence [4].

In Central Africa, commercial hunting strongly contributes to supplying households with animal proteins in rural areas as well as in urban areas. It is accused to overexploit the fauna and to have a very negative impact on animal biodiversity and on forest regeneration, as well as creating important risks due to the development of emerging diseases [5]. On the other hand, biodiversity protection by the population of Upper-Katanga province is less striking/notable as the role or socio-cultural need of the population is absorbed by the economic one which leads to tree cutting, plant uprooting, hunting or to the extinction of certain animal species.

The objective of this paper is to identify and to define the role and the socio-cultural and economic importance of certain species of the biodiversity in the life of the population in Upper-Katanga province.

\section{Methodology}

The study was mainly carried out in the Upper-Katanga province located at $11^{\circ} 40^{\prime} 11^{\prime \prime}$ South and $27^{\circ} 29^{\prime} 00^{\prime \prime}$ East in the South-East of the Democratic Republic of Congo. After the administrative split of the former Katanga province into four new provinces (Lualaba, Tanganyika, Upper-Katanga, Upper-Lomami) in 2015, the Upper-Katanga became one of the current 26 provinces of the country. The province has an area of 132.425 square kilometers $\left(\mathrm{km}^{2}\right)$ and a population of $4,617,000$ inhabitants [6]. It is limited at the North by the East of the Upper-Lomami province and the South of the Tanganyika province, at the East and the South by the Republic of Zambia and, at the Ouest, by the Lualaba province and the Upper-Lomami province. Lubumbashi is the capital city of the Upper-Katanga province. The province has six territories, notably Kambove, Kasenga, Kipushi, Mitwaba, Pweto and Sakania.

For data collection, authors resorted to methods such as observation, field investigation and bibliographical research.

The various products encountered at the four selling sites of Lubumbashi market, notably the Rail, Kaleja and Mpande markets which receive products from Likasi road and Kasenga road, and the Matshipisha market which receives products from Kipushi, Sodimico and Kaponda "chefferie" (a rural county ruled by a traditional chief) on Kasumbalesa road, stem from the forest or the bush. They allowed us to distinguish different socio-professional groups whose roles are, among others, to be used as food, furniture manufacturing, wood frame/timberwork, building structure, sculpture, art works, manufacturing of coffins/caskets, drums, fishing pirogues, royal power signs, etc. Investigation was conducted through interview of target groups. Most questions asked to the surveyed people were open because we needed their opinion and that is why certain terms and/or names of some trees, insects, birds and other animals were written down in their own language or dialect. To that effect, of all the very important trees in the province Sanga, Yeke, Chokwe tribes, etc. (according to the given socio-cultural importance), the only tree (the "Mwemwe tuseko": Sterculia quinqueloba) of which our guides remembered again the location was photographed. The sample was randomly taken. A total of 295 people were questioned. Among them were 15 antelope hunters, 20 sellers of various woods, 80 embers' sellers, 40 wild duck sellers, 30 wood furniture 
Table 1 Questioned people per socio-professional category and quantity sold per working day each week.

\begin{tabular}{lllllllll}
\hline Socio-professional category of & Number of & \multicolumn{9}{c}{$\begin{array}{l}\text { Quantity sold per week } \\
\text { questioned people }\end{array}$} & sellers & Mon & Tue & Wed & Thu & Fri & Sat & Total \\
\hline Antelope hunters & 15 & 4 & 2 & 0 & 1 & 2 & 7 & 16 \\
Wood sellers & 20 & 500 & 600 & 650 & 700 & 550 & 600 & 3,600 \\
Ember sellers & 80 & 30 & 90 & 70 & 30 & 90 & 70 & 380 \\
Kanga (Wild duck) sellers & 40 & 2 & 4 & 5 & 1 & 4 & 6 & 22 \\
Wood furniture sellers & 30 & 5 & 4 & 3 & 5 & 6 & 2 & 25 \\
Straw mat (per m (2) sellers $_{\text {Goose sellers }}^{5}$ & 12 & 14 & 10 & 16 & 20 & 15 & 87 \\
Other birds' sellers & 40 & 13 & 17 & 25 & 30 & 15 & 20 & 120 \\
Pigeon and Guinea fowl sellers & 40 & 20 & 15 & 25 & 20 & 10 & 30 & 120 \\
Catfish and tilapia sellers & 15 & 50 & 45 & 40 & 20 & 30 & 45 & 230 \\
Total & 295 & 25 & 30 & 27 & 15 & 33 & 45 & 175 \\
\hline
\end{tabular}

sellers, 5 straw mat sellers, 40 goose and Guinea fowl sellers, 10 gosling sellers, 40 green pigeon sellers and 15 catfish and tilapia sellers (Table 1). In the same order, certain photographs taken with a Huawei Honor smartphone and a DN6JNAS4DKNV iPad are shown.

\section{Results and Discussion}

3.1 The Role and Importance of Trees and Animals in the Cultural Life of the Population of Upper-Katanga

The statistics of provincial inspection of public health in Lubumbashi city show that during 2002 in Kampemba, Lubumbashi and Ruashi communes, there were in total 100,507 cases of malaria, 10,591 cases of acute respiratory infections, 10,389 cases of diarrhoeic diseases $(9,604$ cases of simple diarrhea and 785 cases of bleeding diarrhea) and 5,826 cases of STI (Sexually Transmissible Infections). Those were the most frequent diseases in the Lubumbashi sanitary district.

To fight against that curse which decimates the population, mostly the poorest, people have to organize themselves according to their region in order to take care of themselves. The bad socio-economic situation faced by developing countries, particularly the DRC (Democratic Republic of Congo), pushes patients to resort to traditional medicine. One of the recent WHO (World Health Organization) reports indicates that $80 \%$ of the world population use natural products, particularly plants to treat himself. Indeed, the traditional medicine resorts to the use of natural products of which the main sources are plants, mushrooms, animals and mineral products [7]. In the Lubumbashi region, traditherapists (traditional therapists) use plants to treat sickle cell anaemia and other various diseases [8].

Medicinal plants occupy a place of choice in the treatment of different pathologies. That reality is mainly observed in developing countries due to several reasons, including the completely deteriorated socio-economic situation, the extreme poverty of the majority of the populations, and cultural considerations [9].

The "biomedicine" does not take into consideration the somatic dimension of the illness whereas the traditional medicine takes care of the somatic as well as the psychic dimensions (a man is considered as a bio-psycho-socio-cultural constituent) [9].

According to the belief of the population in Upper-Katanga province, certain trees and animals present a great socio-cultural importance in the life. That is notably the case of:

(a) The "Mwemwe tuseko" (Sterculia quinqueloba), a white tree of which roots serve to provide chance and good evolution in professional life (Fig. 1).

(b) The "Mutakali", a tree of which trunk and branches are utilized as the pillars on which the drums 

Democratic Republic of Congo: Case of the Upper-Katanga Province

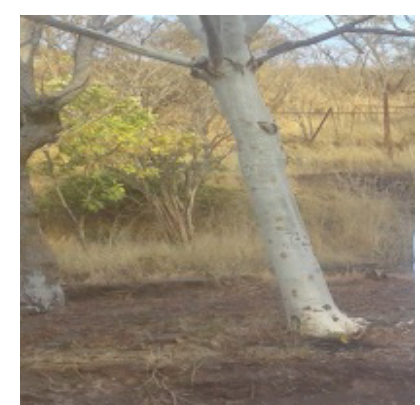

Fig. 1 The Mwemwe tuseko (Sterculia quinqueloba).

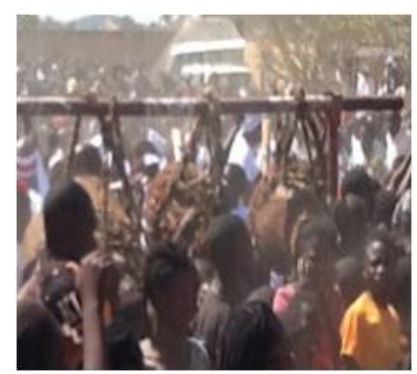

Fig. 2a The Mutakali.

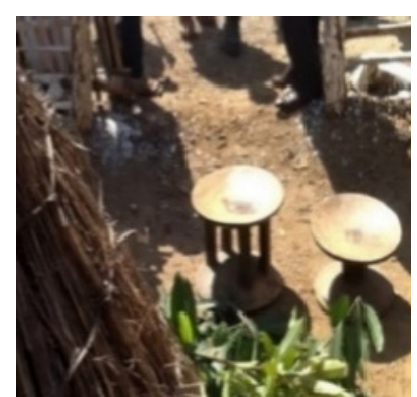

Fig. 2b The Mutakali.

of the Yeke tribe kingdom are hanged (Fig. 2a), the same "Mutakali" also used for manufacturing small chairs on which the king and the queen seat down during different rituals (Fig. 2b).

(c) The "Nkota bagoli", a tree which is among the constraints/tabous in the Yeke tribe and of which, for instance, it is forbidden to the queens to burn for warming themselves up.

(d) The "Mulwalwa", a tree of which the roots are often abusively used for separating couples; it means that it is only enough that the roots of this tree be thrown to the roof of a house to note/observe later on the breaking up of the couple who was living in the house.

(e) The "Mubanga" (Pericopsis angolensis), another tree of which roots and leaves are soaked in bath water by mothers of young children (boys) for their boys to become strong during their childhood.

(f) The "Ndulwe kyulu", a tree of which bitter roots are used for causing abortions.

(g) The "Mutondo" (Julbernadia paniculata), a tree economically good for charcoal-burners as its trunk and branches also produce charcoal.

(h) "Musamba" (Brachystegia wangemeeana or Brachystegia boehmii), a tree of which bark is used as a rope to tie up/to link together hunters' burdens.

(i) The "Mulombwa" (Pterocarpus angolensis), an economically important tree because of the quality of its wood which is appreciated by joiners. The "Mulombwa" produces a hard and beautiful wood, two qualities economically profitable for the joiners as the furniture made from that tree, and attracts customers because of the wood qualities.

(j) "Lion", a very important animal in the Bayeke tribe as it represents the life of the king, and the Bayeke chief is considered as a lion. The skin of the animal serves as a carpet on which the king puts/places his feet onto the main courtyard. The lion tail symbolizes the power of the king (Fig. 3).

(k) "Pangolin", a mammal animal which is not consumed as it causes the kwashiorkor (a malnutrition illness due to protein deficiency) to children, according to the tradition of "Bajila-Kasanga", a tribe of the Central Kasaï province. That tribe forms almost $10 \%$ of the population of the Upper-Katanga province.

Since a long time, certain collectivities protect such or such trees because those trees are used as rallying point or because they assume a sacred character.

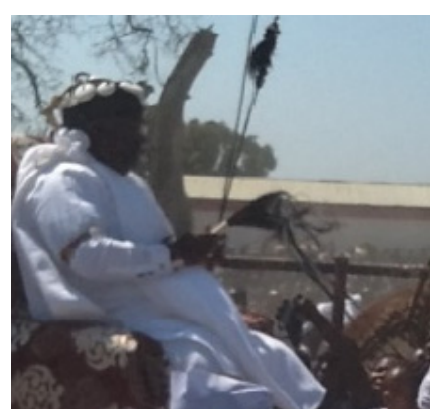

Fig. 3 A lion tail in the hands of the Bayeke chief. 
3.2 The Role and Importance of Forest in the Economic Life of the Population of the Upper-Katanga Province

Economically speaking, biodiversity occupies a great place in the life of the Upper-Katanga population, especially that biodiversity provides the population with many things such as wood for building houses, wood for charcoal/ember making and for charcoal-fired heating in rural area (Fig. 4). The embers constitute more than $80 \%$ of energy consumption by the Upper-Katanga population, they are packed in 50-kg bags (Fig. 5a). They are ignited with ember igniters (Fig. 5b).

Wood is also used for making house equipment such as furniture (Fig. 6a), mixers and mortars (Fig. 6b). Moreover, biodiversity also provides households with food and financial resources through the sale of biodiversity products, etc. The strongest dependence

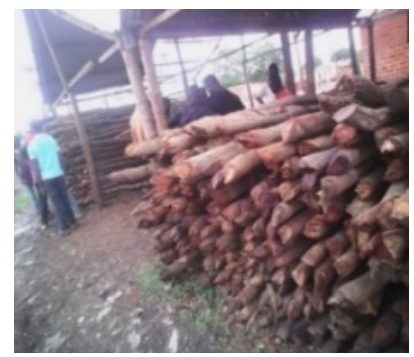

Fig. 4 Construction trees for sale.

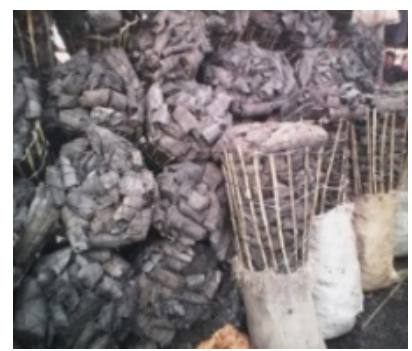

Fig. 5a 50-kg bags of embers for sale.

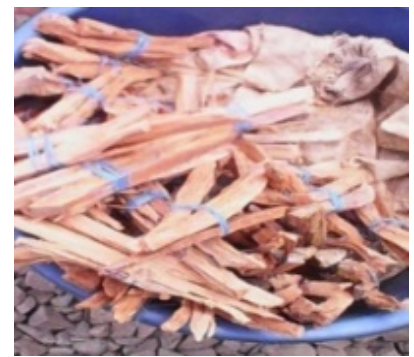

Fig. 5b Ember igniters for sale.

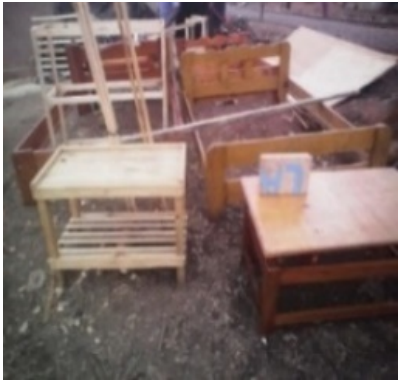

Fig. 6a Wood furniture for sale.

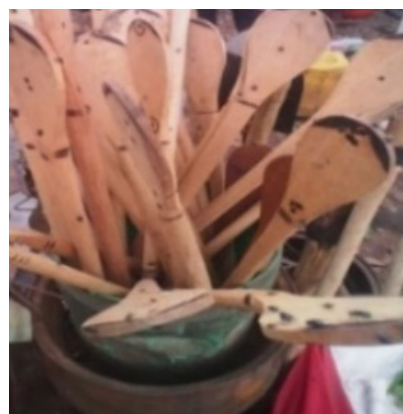

Fig. 6b Mixers for sale in a mortar for sale, too.

toward wood energy is observed in Sub-Saharan African countries where $93 \%$ of the rural population and $58 \%$ of the urban population depend on biomass (such as wood for fire, embers, agricultural waste, animal feces) for combustible [10].

Practically, the food offered to the Upper-Katanga households by the biodiversity concerns notably the antelope that is one of the most consumed meat in the province. It is followed by the goose, the wild duck (also called "Kanga"), the Guinea fowl, the green pigeon, the catfish and the tilapia. Those species of which local demand is considerable represent a very high level of hunting and fishing in the province (Figs. 7a-7d).

The commercial hunting has a long history which started with the Belgian colonization and continued without breaking off but with different actors up to now. The hunting is concerned with small and medium-sized fauna which presents natural dynamics of very high reproduction and which withstands well high hunting pressure [5]. The venison, especially the smoked meat, plays an important role in the food security for the rural and the poorest urban people. Hunting for meat is not with free access but the network is strongly regulated 

Democratic Republic of Congo: Case of the Upper-Katanga Province

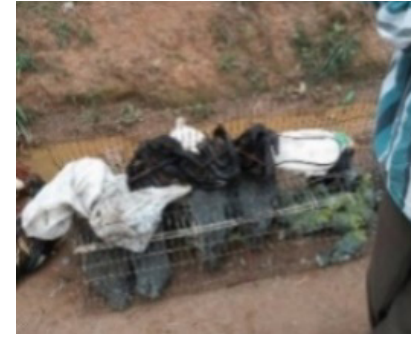

Fig. 7a Guinea fowls and green pigeons alive in a wire-mesh cage and smoked Guinea fowls above the cage.

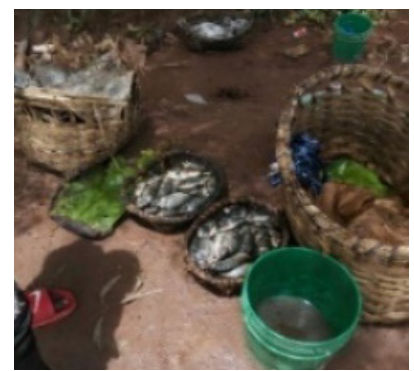

Fig. 7b Tilapia fish in two small baskets.

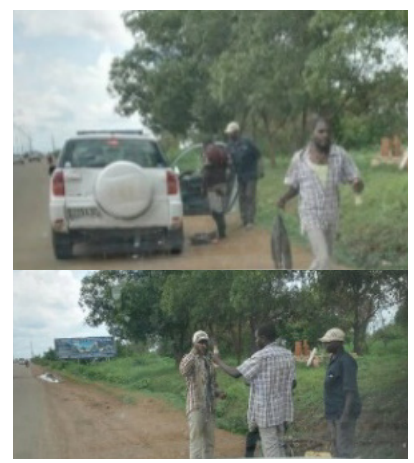

Fig. 7c Catfish hanged with a rope by a seller.

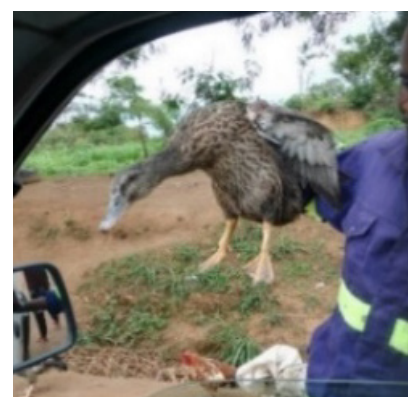

Fig. 7d A wild duck in the right hand of a seller.

by social, economic, geographic and technical constraints [5]. Besides, one can also find in the pots of the Upper-Katanga population the "Maninshi" which are termites having the form of small wasps. They go out of termite mounds at the first great rainfall of the season. They are directly captured under sieve when they go out of their small holes or on tree leaves placed around the holes and on which they climb before flying away. The "Malomba" are termites going out of holes of termite mounds where they are captured at night using paraffin lamps/hurricane-lamps or any other luminous means in rainy season. The "Malomba" in Kisanga dialect are called "Inswa" in Kiswahili.

Rats are captured in the bush or in the fields before, during or after harvesting using traps which are called "Biriba" in Kisanga. The "Nseshi" are reed rats that often live on the river banks or in humid places. They are captured by hunting dogs often during the dry season, from the end of April to October.

The "Nzobe" are antelopes of large size which live in humid places. They are often hunted in dry season and rarely/seldom in rainy season. One can hunt them alone but they are often hunted by group of hunters who use hunting dogs and also by using traps made of copper wires called "Sambo".

Edible caterpillars, that are part of the main non-agricultural products, are strongly consumed in the Upper-Katanga province.

Secondly, financial resources are guaranteed through selling of the cited products or species drawn from the biodiversity to satisfy other needs that would not be satisfied otherwise (Tables 1-3; Figs. 8-20).

The budget of the Upper-Katanga province is made/constituted of $80 \%$ of mining exploitation/activities but the main activities in the province are notably the small trade that occupies the first place (50\%), followed by industrial and artisanal mining activities $(25 \%)$, then urban and peri-urban truck gardening $(22 \%)$, and farming (3\%). Agriculture, small trade and faming together account for $19.9 \%$ in the province budget. The biodiversity products encountered on the social, cultural, economic and sanitary markets constitute a small portion in terms of contribution to the budget of the province, especially that those products are illicit. This means that the trees and animals are clandestinely cut or killed and that is why no reforestation is done after deforestation. It is only from sanitary service offered by traditherapists at the level 
Democratic Republic of Congo: Case of the Upper-Katanga Province

Table 2 Embers production with a frequency of twice a week.

\begin{tabular}{|c|c|c|c|c|c|}
\hline Category & Charcoal & Quantity & $\begin{array}{l}\mathrm{PU} \\
\text { (in CDF) }\end{array}$ & $\begin{array}{l}\mathrm{TP} \\
\text { (in CDF) }\end{array}$ & $\begin{array}{l}\mathrm{TP} \\
\text { (in USD*) }\end{array}$ \\
\hline \multirow{2}{*}{ Furnace (Kibiri) } & $\begin{array}{l}4 \text { trees } \\
\text { (furnace of } 3 \mathrm{~m} \text { long } \times 2 \mathrm{~m} \text { wide } \times 2 \mathrm{~m} \text { high) }\end{array}$ & 30 bags & 9,000 & 270,000 & 163.64 \\
\hline & $\begin{array}{l}12 \text { trees } \\
\text { (furnace of } 10 \mathrm{~m} \text { long } \times 5 \mathrm{~m} \text { wide } \times 2 \mathrm{~m} \text { high) }\end{array}$ & 90 bags & 9,000 & 810,000 & 490.91 \\
\hline $\begin{array}{l}\text { Tree field of } 50 \mathrm{~m} \text { long } \times \\
25 \mathrm{~m} \text { wide for a charcoal } \\
\text { furnace }\end{array}$ & Furnace of $8 \mathrm{~m}$ long $\times 4 \mathrm{~m}$ wide $\times 2 \mathrm{~m}$ high & 70 bags & 9,000 & 630,000 & 381.82 \\
\hline Total & 16 trees and a charcoal field of $50 \mathrm{~m} \times 25 \mathrm{~m}$ & 190 bags & 9,000 & $1,710,000$ & $1,036.37$ \\
\hline Total multiplied by & a mean of 20 charcoal sellers per sale point & 3,800 bags & 9,000 & $34,200,000$ & $20,727.27$ \\
\hline
\end{tabular}

CDF: Congolese franc; PU: price per unit; TP: total price; USD: United States of America dollar; * 1 USD = 1,650 CDF.

Table 3 Types of animals sold at the market.

\begin{tabular}{llllll}
\hline Animal type & Quantity & $\begin{array}{l}\text { Price } \\
\text { (in CDF) }\end{array}$ & Quantity & $\begin{array}{l}\text { Price } \\
\text { (in CDF) }\end{array}$ & $\begin{array}{l}\text { Price } \\
\text { (in USD*) }\end{array}$ \\
\hline Antelope & 1 portion & 30,000 & $1 \times 4$ portions & 120,000 & 72.73 \\
Kanga (Wild duck) & 2 portions & 50,000 & $2 \times 2$ portions & 100,000 & 60.61 \\
Goose & 1 & 65,000 & 1 & 65,000 & 39.39 \\
Pigeon & 1 & 5,500 & 1 & 5,500 & 3.33 \\
Guinea fowl & 1 & 25,000 & 1 & 25,000 & 15.15 \\
Catfish & 1 & 5,000 & 1 & 5,000 & 3.03 \\
Tilapia & 1 straw basin & 5,000 & 1 & 5,000 & 3.03 \\
\hline
\end{tabular}

CDF: Congolese franc; USD: United States of America dollar; * 1 USD = 1,650 CDF.

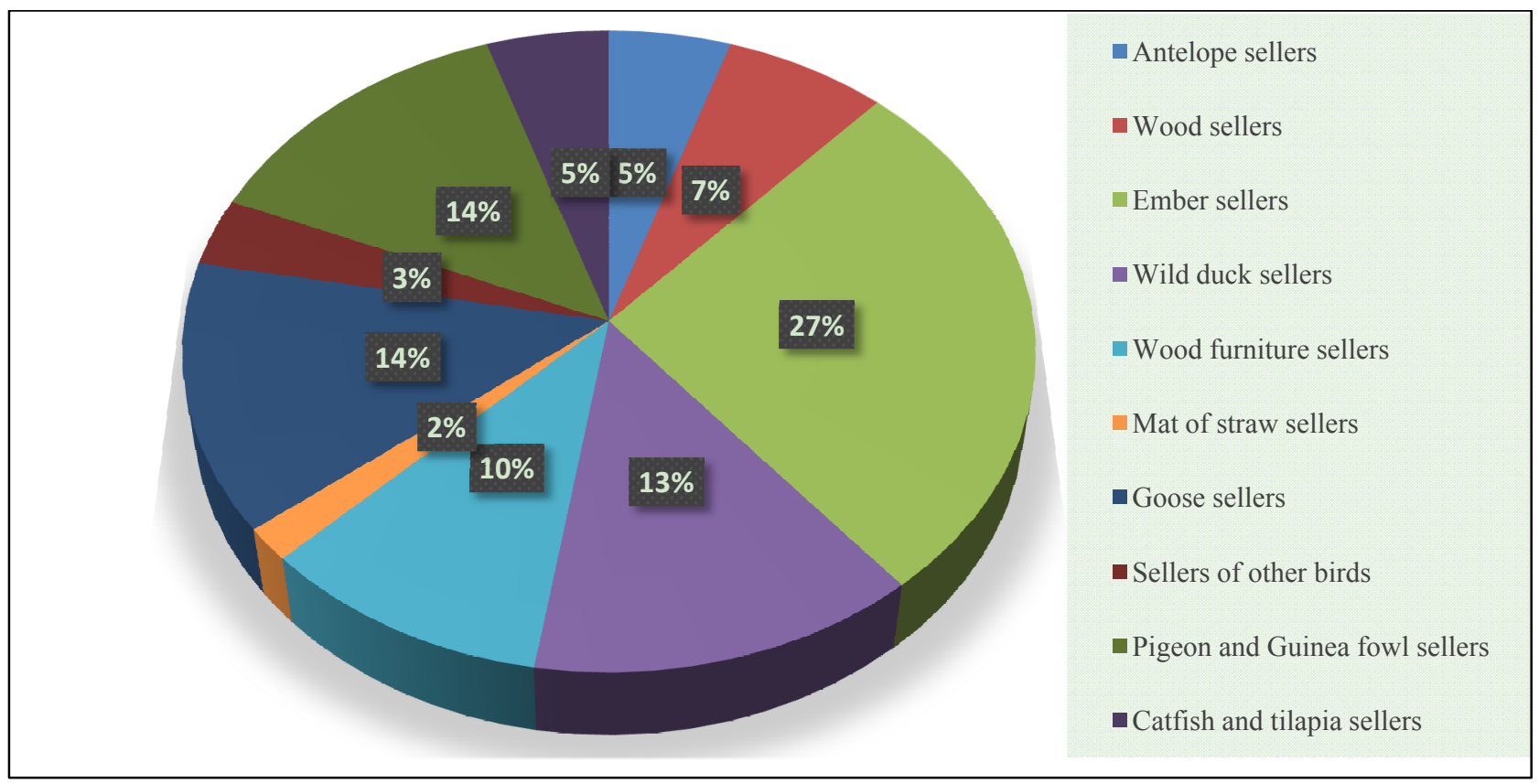

Fig. 8 Surveyed people per socio-professional category. 

Democratic Republic of Congo: Case of the Upper-Katanga Province

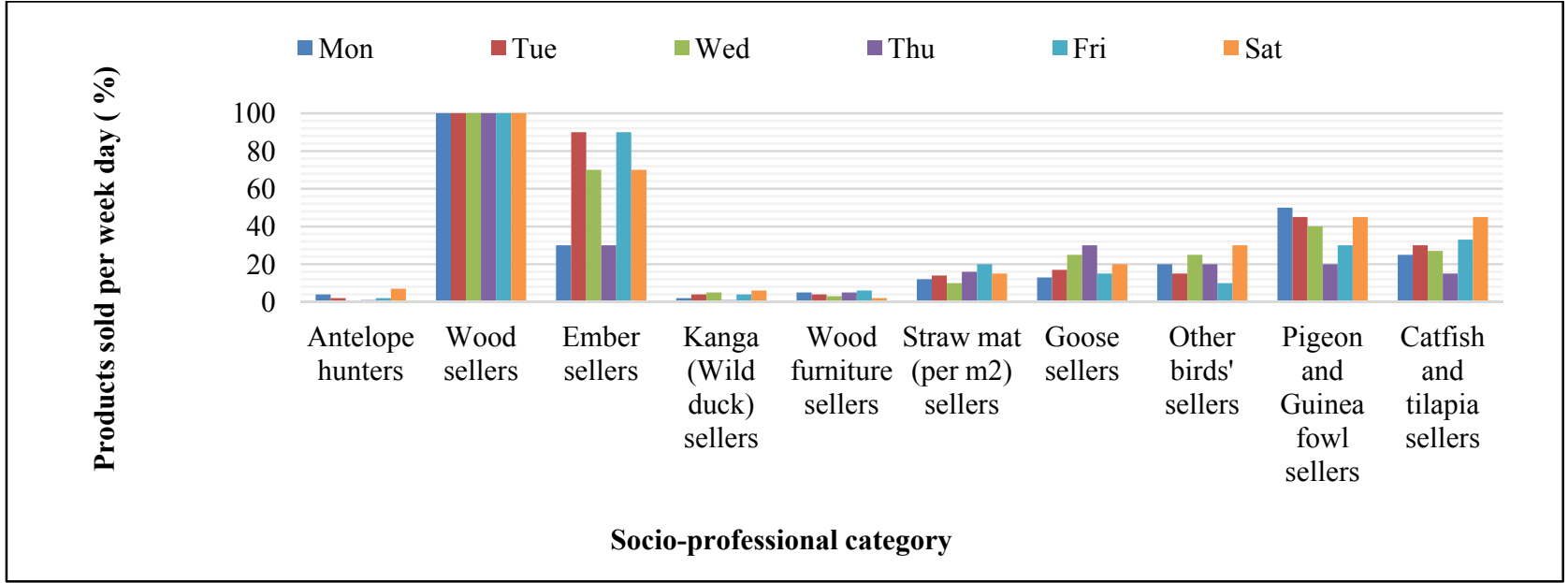

Fig. 9 Frequency of product sale per socio-professional category.

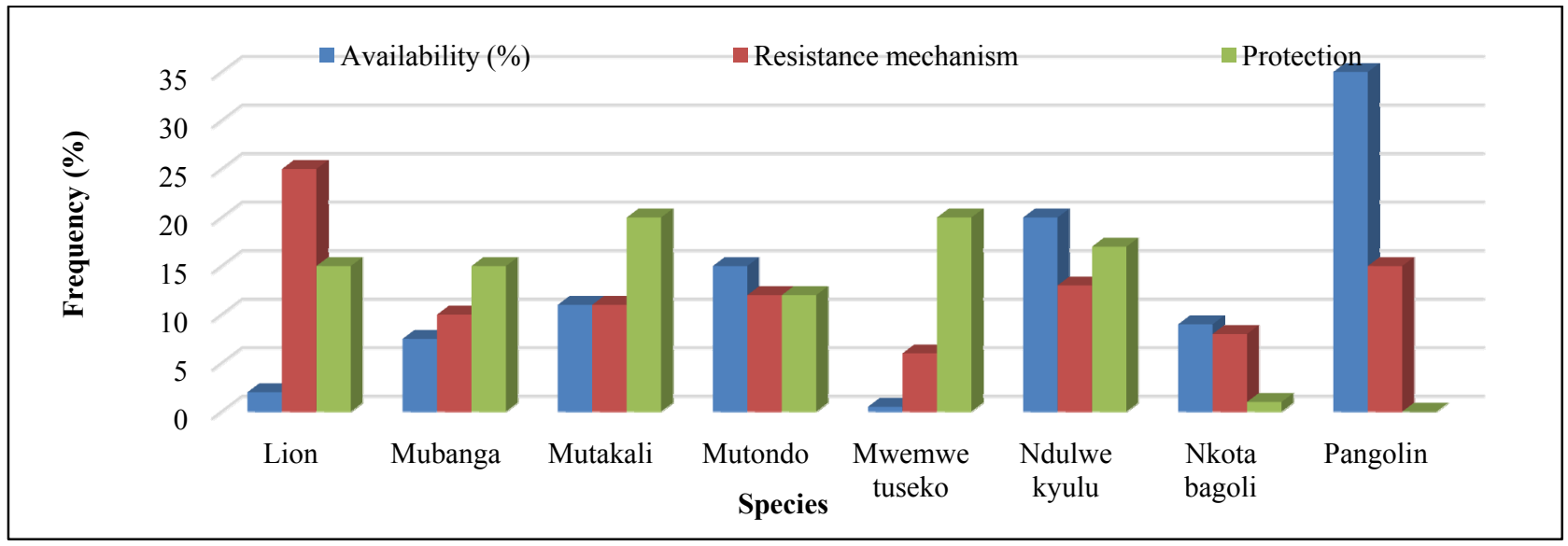

Fig. 10 The socio-cultural role and importance of biodiversity.

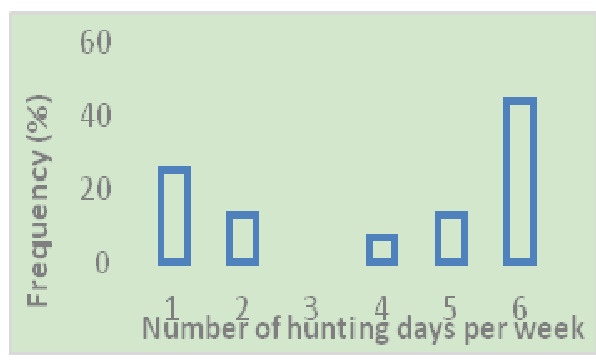

Fig. 11 Frequency of antelope hunting days per week.

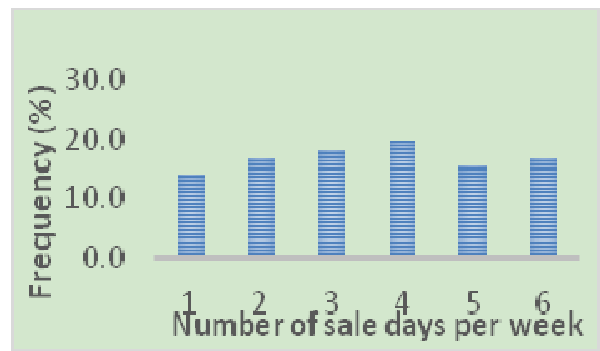

Fig. 12 Frequency of wood sale days per week.

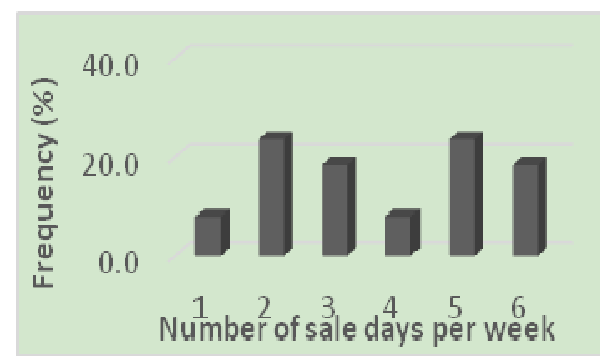

Fig. 13 Frequency of embers sale days per week.

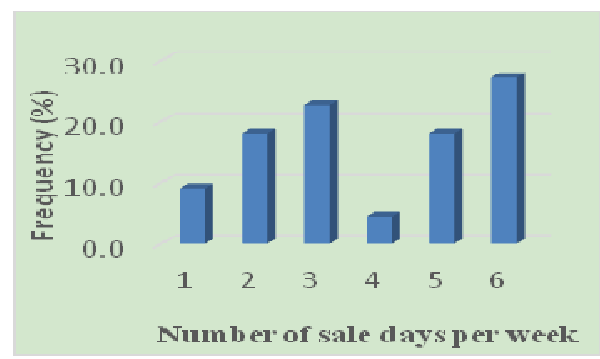

Fig. 14 Frequency of wild duck sale days per week. 


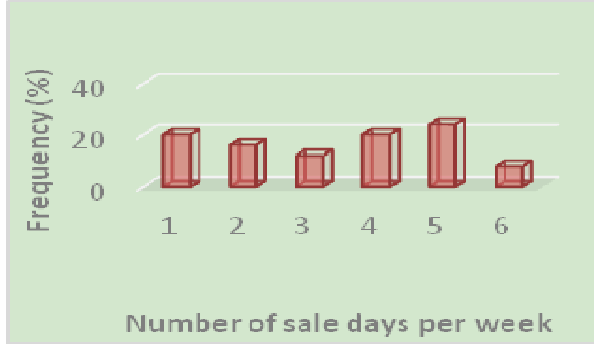

Fig. 15 Frequency of wood furniture sale days per week.

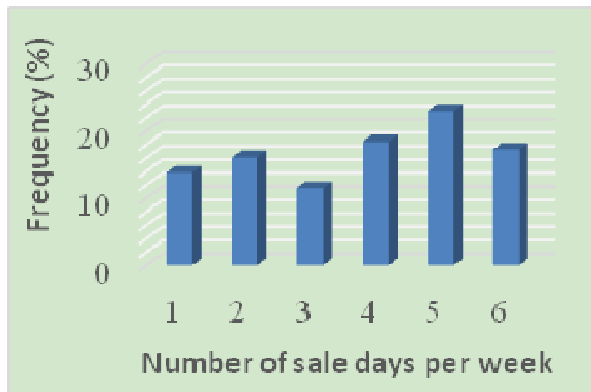

Fig. 16 Frequency of straw mats (per $\mathrm{m}^{2}$ ) sale days per week.

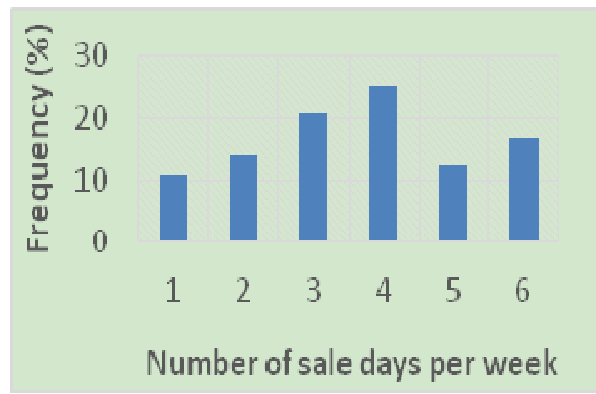

Fig. 17 Frequency of goose sale days per week.

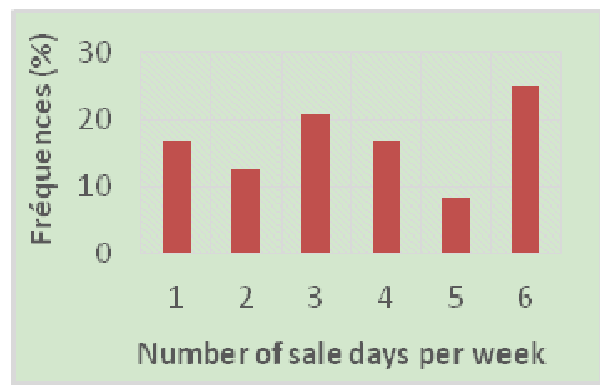

Fig. 18 Frequency of gosling sale days per week.

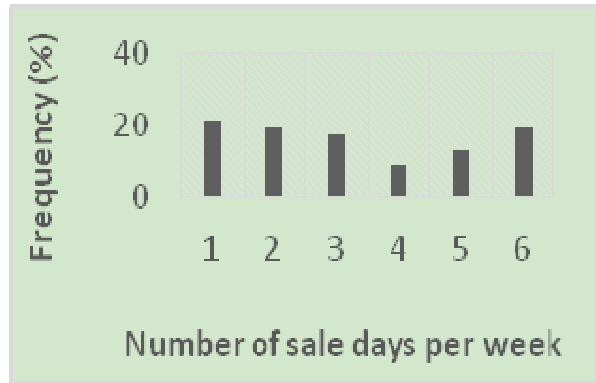

Fig. 19 Frequency of green pigeon sale days per week.

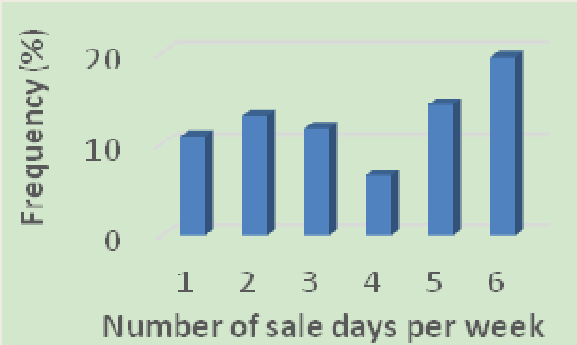

Fig. 20 Frequency of catfish and tilapia sale days per week.

of $95 \%$ and whose actors are required to pay for administration and other expenses necessary for the functioning of the province.

\section{Conclusion}

The biodiversity and forest play various important roles in the life of the Upper-Katanga population. This study brings light to different spheres of the daily life of the same population through the trees and animals they utilize under cultural, economic and social forms. On one side, the trees are culturally used in the king's yard, for breaking up couples, for causing abortion and, on the other side, in an economic manner by constituting financial resources through selling charcoal/embers (wood energy), wood for construction and wood for making furniture. Various plants and mushrooms are used by tradition medicine to treat different diseases. Animals too are utilized in the same cultural and economic contexts. The lion tail and skin are considered as a source of authority and power for the king. The hunted and captured animals are consumed or sold by the population. The importance, more economic at $99.99 \%$ than socio-cultural (0.01\%), given to those species pushes to an overexploitation which threatens those animals with extinction.

\section{Acknowledgements}

Authors are grateful to Mr. Clément Kalombo Assistant and Mr. Désiré Mujike, both assistant lecturers at the Faculty of Agricultural Science, University of Lubumbashi for having provided them with the scientific names of some of the animal and plant species mentioned in this paper. 


\section{References}

[1] Hainzelin, E. 2013. To Cultivate the Biodiversity in Order to Transform the Agriculture. Edited by Quae, Paris.

[2] Garnier, E., and Navas, M.-L. 2013. Functional Diversity of Plants: Organism Traits, Community Structure, Ecosystem Properties. Edited by De Boeck, Brussels.

[3] Adjovi, E. C., Amadji, T. A., and Olodo, E. 2017. "Importance and Role of Biodiversity and Tropical Forests in the Cultural, Socio-Economic and Religious Life of African Black People: Case of Benin.” Journal of Environmental Science and Engineering B 6 (6): 312-22.

[4] Wilungula, C. B. 2007. "The Biodiversity and the Protected Areas in Democratic Republic of Congo". In International Conference on the Congo, 26-27 February 2007. Egmont Palace, Brussels. http://fr.carpe.umd.edu/Documents/2008/Etat-des-forets 2008-01.pdf. Accessed October 28, 2017.

[5] Fargeot, C. 2013. "Commercial Hunting in Central Africa. A Threat for the Biodiversity or a Sustainable Economic Activity? The Case of the Central African Republic." Ph.D. Dissertation, Geography and Space Planning, Montpellier University.
[6] National Institute of Statistics, Dem. Rep. Congo 2015. Congo (Dem. Rep.) Provinces. https://citypopulation.de/CongoDemRep-Cities.html. Accessed September 13, 2018.

[7] Ngoy, K. M. E. 2009. "Study of Some Plants Renowned for Being Antidiarrhoeic in Use in Lubumbashi and Its Neighborhood." M.Sc. thesis, Faculty of Science, University of Lubumbashi.

[8] Kanangila, B. A.-L. 2011. "Chemical Screening and Antifalcemiant Activity of Some Plants Renowned for Being Used as Anti-sickle Cell Anemia in Lubumbashi and Its Neighborhood." M.Sc. thesis, Faculty of Science, University of Lubumbashi.

[9] Ngoy, K. M. E. 2013 "Phytochemical Study of Crossopteryx febrifuga and Terminalia mollis, Two Plants Renowned for Being Antidiarrhoeic in Use in Lubumbashi and Its Neighborhood.” Ph.D. dissertation, Faculty of Science, University of Lubumbashi.

[10] Schure, J., Assembe, S. M., Awono, A., Ingram V., Lescuyer, G., Sonwa, D., and Somorin, O. 2010. "The State of the Art of Energy Wood in DRC: Institutional and Socio-Economic Analysis of the Energy Wood Channels.” In CIFOR (Center for International Forestry Research). 